\title{
PENGARUH PENYAKIT KRONIS DAN GAYA HIDUP TERHADAP KINERJA VERBAL FLUENCY KATEGORIK PADA LANSIA
}

\author{
CHRONIC DISEASES AND LIFESTYLE IMPACT TO CATEGORY VERBAL \\ FLUENCY PERFORMANCE IN ELDERLY
}

Jessica Alysia, * Yvonne Suzy Handajani, * Nelly Tina Widjaja, * Yuda Turana*

\section{ABSTRACT}

Introduction: In recent studies, chronic illness and sedentary lifestyle were found to bea risk factors for cognitive impairment. Verbal fluency (VF) is one of the most used instruments. in elderly.

Aim: To determine cognitive impairment using VF and its correlation with risk factors (chronic illness and lifestyle)

Method: This cross-sectional study was conducted toward 121 elderly respondents in August-September 2017 at Pusaka, West Jakarta. Cognitive impariment was assessesed using VF. VF otherwise disturbed if the value $<16.03$. Heart disease and stroke were determined by anamnesis. Blood pressure was determined using Riester tensimeter. that has been calibrated. Cholesterol and blood sugar were determined using laboratory result by CHOD-PAP method. Smoking was determined by asking the history of smoking. Physical activity was determined by 24-hour activity recall. Nutrition Intake was determined by food record.

Results: There were $63.6 \%$ subjects wno had VF impairment. Most respondent were over 65 years old (71.9\%), female (66.1\%) and education level more than 6 years (72.7\%). VF had a significant assosiation with education level $(p=0.020 ;$ OR $=3.792)$, and without cardiovascular disease $(p=0.023 ; O R=0.111)$.

Discussion: The mayority of respondents had VF impairment, lower education was consistenly as a risk factors while no history of cardiovascular disease as a protective factors of language impairment.

Keywords: Chronic diseases, cognitive impairment, lifestyle, verbal fluency

\section{ABSTRAK}

Pendahuluan: Pada beberapa penelitian terbaru ditemukan bahwa faktor risiko seperti penyakit kronis dan gaya hidup buruk meningkatkan risiko terkena gangguan fungsi kognitif. Salah satu instrumen yang sering digunakan adalah verbal fluency $(\mathrm{VF})$.

Tujuan: Mengetahui gambaran fungsi kognitif dengan instrumen VF dan hubungannya dengan faktor risiko (penyakit kronis dan gaya hidup) pada lansia.

Metode: Penelitian potong lintang ini dilaksanakan pada 121 responden lansia pada bulan Agustus-September 2017 di Pusaka Jakarta Barat. Gangguan fungsi kognitif dinilai menggunakan instrumen VF. Verbal fluency dikatakan terganggu dengan nilai $<16,03$. Penyakit jantung dan stroke didapatkan dari anamnesis. Tekanan darah dari hasil pengukuran menggunakan tensimeter yang telah dikalibrasi sebelumnya. Pengukuran kolesterol dan gula darah didapatkan dari hasil laboratorium dengan metode CHOD-PAP. Merokok didapat dari anamnesis. Aktivitas fisik dinilai dari 24-hour activity recall. Asupan nutrisi dinilai dari kuisioner food record.

Hasil: Hasil penelitian ini menunjukkan subjek dengan gangguan VF sebanyak 63,6\%. Mayoritas responden berusia diatas 65 tahun $(71,9 \%)$, dengan jenis kelamin wanita (66,1\%) dan tingkat pendidikan diatas 6 tahun (72,7\%). Hasil analisis menunjukan bahwa instrumen VF memiliki hubungan bermakna dengan tingkat pendidikan rendah $(\mathrm{p}=0,020 ; \mathrm{RO}=3,792)$, dan tidak berpenyakit jantung $(\mathrm{p}=0,023 ; \mathrm{RO}=0,111)$.

Diskusi: Mayoritas responden memiliki gangguan bahasa, pendidikan rendah diketahui secara konsisten sebagai faktor risiko sementara tidak ada riwayat penyakit jantung sebagai faktor protektif untuk gangguan fungsi bahasa.

Kata kunci: Gangguan fungsi kognitif, gaya hidup, penyakit kronis, verbal fluency

*FKIK Universitas Katolik Atma Jaya, Jakarta. Korespondensi: yudaturana@atmajaya.ac.id.

\section{PENDAHULUAN}

Pada tahun 2014, jumlah penduduk lanjut usia (lansia) di Indonesia mencapai 20,24 juta jiwa $(8,03 \%)$ dari seluruh penduduk Indonesia dan diperkirakan akan terus bertambah hingga $15,8 \%$ pada tahun 2035..$^{1-2}$ Total lansia di seluruh dunia mencapai 617 juta jiwa dengan presentase $8,5 \%$. Meningkatnya jumlah lansia tiap tahun akan menyebabkan mereka lebih terbebani dengan komplikasi akibat penyakit kronis tidak menular yang disebabkan proses penuaan patologis, salah satunya adalah gangguan fungsi kognitif. ${ }^{1}$ Risiko terjadinya gangguan kognitif 
pada lansia berusia 65 tahun adalah 5\% tetapi pada usia diatas 85 tahun angka ini meningkat menjadi lebih dari $40 \%$. Angka tersebut juga diprediksi akan meningkat 3 kali lipat pada tahun 2050. ${ }^{3}$

Verbal fluency (VF) merupakan salah satu jenis instrumen yang singkat, mudah dan sering digunakan untuk mengukur kemampuan verbal seseorang, selain itu instrumen ini juga telah dibuktikan dapat menilai fungsi lobus frontal, memori semantik dan fungsi eksekutif. Instrumen ini umumnya digunakan sebagai tes neurofisiologi, terutama sebagai alat skrining untuk diagnosis tahap awal penyakit Parkinson dan penyakit Alzheimer yang ditandai dengan penurunan fungsi organisasi, kemampuan semantik, dan gangguan fungsi eksekutif. Selain itu dapat digunakan juga untuk membedakan subtipe demensia..-6 Verbal fluency kategorik terdiri dari beberapa kategori kata, seperti binatang, buahbuahan, nama sayuran, makanan, pekerjaan, nama perempuan dan laki-laki. Kategori yang paling sering digunakan adalah kategori nama binatang dan termasuk sebagai salah satu tes dalam Consortium for the Establishment of a Registry for Alzheirmer's Disease (CERAD) untuk demensia dan penyakit Alzheimer. Hasil skor kategorik nama binatang merupakan pengukuran yang paling sensitif untuk membedakan penuaan normal dengan demensia.

Pada beberapa penelitian beberapa tahun terakhir ditemukan bahwa prevalensi penyakit kronis dan gaya hidup yang buruk meningkat sehingga dapat meningkatkan risiko gangguan fungsi kognitif di usia tua. Penyakit kronis seperti obesitas yang pada jangka panjang dapat menjadi faktor risiko untuk demensia vaskuler karena berpotensi menyebabkan hipertensi, dislipidemia, diabetes, penyakit jantung, stroke, dan sindrom metabolik. ${ }^{7}$ Gaya hidup yang sehat seperti cara makan dan olahraga telah dikaitkan dengan penurunan risiko penyakit kronis sedangkan hubungannya dengan fungsi kognitif, ada beberapa peneltian yang menyatakan bahwa gaya hidup sehat menjaga fungsi memori pada lansia, tapi ada juga yang menolak. ${ }^{8}$

Gangguan fungsi kognitif pada lansia dapat mengganggu aktivitas sehari-hari dan kualitas hidup pada lansia, tetapi beberapa penelitian yang telah dilakukan lebih banyak menilai fungsi kognitif dalam ranah memori, sedangkan penelitian kami berfokus dalam ranah kemampuan bahasa yaitu dengan VF. Oleh karena itu, penelitian ini bertujuan untuk mengetahui kinerja VF dan hubungannya dengan faktor risiko (penyakit kronis dan gaya hidup) pada lansia.

\section{METODE}

Penelitian ini merupakan penelitian deskriptif analitik dengan pengambilan data secara potong lintang ini dilakukan pada lansia di Pusaka (Pusat Santunan Keluarga) Jakarta Barat. Penelitian ini berlangsung pada bulan Agustus 2017 sampai September 2017. Besar sampel pada penelitian ini berjumlah 121 responden.

Instrumen VF digunakan untuk mengukur kemampuan verbal seseorang. Verbal fluency dikatakan terganggu jika mendapat nilai $<16,03$, yaitu rerata nilai tengah pada jurnal yang meneliti pemeriksaan neuropsikologi CERAD di Jakarta. ${ }^{9}$ Penyakit jantung dan stroke dinilai dari riwayat penyakit. Tekanan darah didapatkan dari hasil pengukuran menggunakan tensi meter yang sudah dikalibrasi sebelumnya. Pengkategorian hipertensi berdasarkan JNC-7, bila hasil pengukuran diatas 140/90mmHg dikategorikan sebagai hipertensi. ${ }^{10}$ Indeks massa tubuh (IMT) didapatkan dari pengukuran tinggi badan dan berat badan dengan menggunakan timbangan yang telah dikalibrasi dan dikategorikan berdasarkan WHO Asia yang menunjukan seseorang menderita obesitas jika IMT $>25 .{ }^{11}$ Pengukuran kolesterol dan gula darah didapatkan dari hasil laboratorium dengan pungsi vena sebanyak $10 \mathrm{~mL}$, profil lipid meliputi pemeriksaan kolesterol LDL, kolesterol HDL dalam darah dengan metode CHOD-PAP. Pengukuran profil lipid darah ini dilakukan dalam keadaan puasa kurang lebih 10 jam. Pengambilan sampel darah dilakukan oleh petugas khusus dari pihak laboratorium Prodia. Pengambilan darah dilakukan pagi oleh laboratorium Prodia, sekitar jam 08.00 setelah responden melakukan puasa 12 jam. Prosedur pemeriksaan darah adalah berdasarkan UV test dengan metode heksokinase. Kolesterol dikategorikan berdasarkan 
klasifikasi Nielsen yang menyatakan seseorang menderita dislipidemia jika kadar kolestrol total $\geq 200 \mathrm{mg} / \mathrm{dL}$, kolesterol LDL $\geq 100 \mathrm{mg} / \mathrm{dL}$, kolesterol $\mathrm{HDL}<40 \mathrm{mg} / \mathrm{dL}$, trigliserida $\geq 150 \mathrm{mg} / \mathrm{dL} .{ }^{12}$ Gula darah dikategorikan dengan menggunakan kriteria WHO yang menunjukan seseorang menderita diabetes melitus jika gula darah $\geq 126 \mathrm{mg} / \mathrm{dL}^{13}$ Merokok dinilai dari riwayat merokok. Aktivitas fisik dinilai dari activity recall 24 jam dan dikategorikan berdasarkan National Institute of Health (NIH) yang menunjukan aktivitas fisik aktif jika hasil pengukuran physical activity level (PAL) $\geq 1,4 .{ }^{14}$ Asupan nutrisi dinilai dari kuisioner food record dan dikategorikan berdasarkan Widyakarya Nasional Pangan dan Gizi VIII tahun 2004 yang menunjukan asupan nutrisi cukup jika $\geq 90 \%$ dari kebutuhan energi total, karbohidrat, lemak, dan protein. ${ }^{15}$

Kriteria inklusi pada penelitian ini adalah lansia dengan usia $\geq 60$ tahun. Kriteria eksklusi pada penelitian ini adalah lansia tidak dapat berkomunikasi, tidak dapat membaca dan menulis serta tidak bersedia untuk diwawancarai. Penyajian dan analisis data menggunakan software SPSS dengan menggunakan uji Chi-square pada analisis bivariat dan regresi logistik pada analisis multivariat untuk melihat hubungan penyakit kronis dan gaya hidup terhadap kinerja VF kategori pada lansia. Hasil analisis dinyatakan bermakna bila didapatkan $p<0,05$. Penelitian ini telah lulus uji etik Fakultas Kedokteran Universitas Katolik Indonesia Atma Jaya dengan nomor 05/01/KEP-FKUAJ/2018.

\section{HASIL}

Hasil penelitian ini menunjukkan subjek dengan gangguan VF sebanyak 77 (63,6\%). Jenis kelamin terbanyak adalah perempuan $(66,1 \%)$, berusia 65 tahun $(71,9 \%)$. Karakteristik dasar responden dapat dilihat pada tabel 1. Mayoritas responden tidak merokok, cukup melakukan aktivitas fisik, dan untuk asupan nutrisi, mayoritas responden belum mendapat asupan nutrisi energi, asupan protein, lemak dan karbohidrat yang cukup (Tabel 1).

Hasil analisis bivariat, menunjukkan bahwa faktor pendidikan $(\mathrm{p}=0,006)$ dan penyakit stroke $(p=0,013)$ memiliki hubungan bermakna dengan penurunan fungsi kognitif (Tabel 2).
Tabel 1. Karakteristik Responden

\begin{tabular}{lc}
\hline \multicolumn{1}{c}{ Variabel } & n (\%) \\
\hline Sosiodemografi & \\
- Perempuan & $80(66,1 \%)$ \\
- 65 tahun & $87(71,9 \%)$ \\
- Pendidikan <6 tahun & $33(17,3 \%)$ \\
- Fungsi bahasa terganggu & $77(63,6 \%)$ \\
Penyakit Kronis & \\
- Obesitas & $80(66,1 \%)$ \\
- Penyakit jantung & $10(8,3 \%)$ \\
- Stroke & $10(8,3 \%)$ \\
- Hipertensi & $61(50,4 \%)$ \\
- Tinggi kolesterol total & $76(62,8 \%)$ \\
- Tinggi LDL* & $59(48,8 \%)$ \\
- Rendah HDL* & $15(12,4 \%)$ \\
- Tinggi trigliserida & $35(28,9 \%)$ \\
- Diabetes melitus & $18(14,9 \%)$ \\
Gaya Hidup dan Asupan Gizi & \\
- Merokok & $18(14,9 \%)$ \\
- Kurang aktivitas fisik & $21(17,4 \%)$ \\
- Tidak cukup asupan energi & $68(56,2 \%)$ \\
- Tidak cukup asupan protein & $84(69,4 \%)$ \\
- Tidak cukup asupan lemak & $77(63,6 \%)$ \\
\hline
\end{tabular}

*LDL: low-density lipoprotein; HDL: high-density lipoportein.

Hasil analisis multivariat menggunakan regresi logistik menunjukkan variabel yang memiliki hubungan bermakna dengan gangguan VF adalah penyakit jantung $(\mathrm{p}=0,02 ; \mathrm{RO}=0,11 ; 95 \% \mathrm{CI}=0,02$ $0,74)$ dan tingkat pendidikan $(\mathrm{p}=0,006 ; \mathrm{RO}=5,53$; $95 \%$ IK=1,62-18,86). Pendidikan diketahui sebagai faktor dominan terhadap risiko gangguan VF pada lansia. Subjek dengan tingkat pendidikan $<6$ tahun memiliki risiko 3,8 kali untuk mengalami gangguan VF dibandingkan subjek dengan pendidikan $\geq 6$ tahun (Tabel 3).

\section{PEMBAHASAN}

Verbal fluency adalah instrumen yang sering digunakan dan dapat dipercaya untuk pengukuran kemampuan verbal dan eksekutif. Umumnya jenis VF yang digunakan adalah kategori nama binatang karena tidak terbatas bahasa dan budaya ${ }^{4}$

Pada penelitian ini tingkat pendidikan memiliki hubungan yang paling bermakna dengan VF pada 
Tabel 2. Hubungan Karakteristik Demografi, Penyakit Kronis dan Gaya Hidup Terhadap Fungsi Bahasa

\begin{tabular}{|c|c|c|c|c|}
\hline \multirow[b]{2}{*}{ Variabel } & \multicolumn{2}{|c|}{ Fungsi Bahasa } & \multirow[b]{2}{*}{$\mathbf{p}^{*}$} & \multirow[b]{2}{*}{ RO } \\
\hline & $\begin{array}{c}\text { Terganggu } n=77 \\
\mathbf{n}(\%)\end{array}$ & $\begin{array}{c}\text { Tidak Terganggu } n=44 \\
\text { n(\%) }\end{array}$ & & \\
\hline \multicolumn{5}{|l|}{ Usia } \\
\hline - $\geq 65$ tahun & $58(66,7)$ & $29(33,3)$ & 0,369 & 1,58 \\
\hline - 60-64 tahun & $19(55,9)$ & $15(44,1)$ & & \\
\hline \multicolumn{5}{|l|}{ Tingkat Pendidikan } \\
\hline - $\geq 6$ tahun & $28(84,8)$ & $5(15,2)$ & 0,006 & 4,45 \\
\hline - $<6$ tahun & $49(55,7)$ & $39(44,3)$ & & \\
\hline \multicolumn{5}{|l|}{ Jenis Kelamin } \\
\hline - Laki-laki & $27(65,9)$ & $14(34,1)$ & 0,87 & 1,15 \\
\hline - Perempuan & $50(62,5)$ & $30(37,5)$ & & \\
\hline \multicolumn{5}{|l|}{ Indeks Massa Tubuh } \\
\hline - Obesitas & $35(64,8)$ & $19(35,2)$ & 0,959 & 1,09 \\
\hline - Normal & $42(62,7)$ & $25(37,3)$ & & \\
\hline \multicolumn{5}{|l|}{ Penyakit Jantung } \\
\hline - $\mathrm{Ya}$ & $4(40)$ & $6(60)$ & 0,167 & 0,35 \\
\hline - Tidak & $73(65,8)$ & $38(34,2)$ & & \\
\hline \multicolumn{5}{|l|}{ Stroke } \\
\hline - Ya & $10(100)$ & $0(0)$ & 0,013 & 0,87 \\
\hline - Tidak & $67(60,4)$ & $44(39,6)$ & & \\
\hline \multicolumn{5}{|l|}{ Hipertensi } \\
\hline - Ya & $40(65,6)$ & $21(34,4)$ & 0,797 & 1,18 \\
\hline - Tidak & $37(61,7)$ & $23(38,3)$ & & \\
\hline \multicolumn{5}{|l|}{ Kolesterol Total } \\
\hline - Ya & $47(61,8)$ & $29(38,2)$ & 0,736 & 1,23 \\
\hline - Tidak & $30(66,7)$ & $15(33,3)$ & & \\
\hline \multicolumn{5}{|l|}{ LDL } \\
\hline - Tinggi & $36(61)$ & $23(39)$ & 0,693 & 0,80 \\
\hline - Normal & $41(66,1)$ & $21(33,9)$ & & \\
\hline \multicolumn{5}{|l|}{ HDL } \\
\hline - Rendah & $9(60)$ & $6(40)$ & 0,979 & 0,84 \\
\hline - Normal & $68(64,2)$ & $38(35,8)$ & & \\
\hline \multicolumn{5}{|l|}{ Trigliserida } \\
\hline - Tinggi & $26(74,3)$ & $9(25,7)$ & 0,179 & 1,98 \\
\hline - Normal & $51(59,3)$ & $35(40,7)$ & & \\
\hline \multicolumn{5}{|l|}{ Diabetes Melitus } \\
\hline - Ya & $14(77,8)$ & $4(22,2)$ & 0,277 & 2,22 \\
\hline - Tidak & $63(61,2)$ & $35(40,7)$ & & \\
\hline \multicolumn{5}{|l|}{ Merokok } \\
\hline - Merokok & $14(77,8)$ & $4(22,2)$ & 0,277 & 2,22 \\
\hline - Tidak & $63(61,2)$ & $40(38,8)$ & & \\
\hline \multicolumn{5}{|l|}{ Aktivitas Fisik } \\
\hline - Kurang & $17(81)$ & 4 (19) & 0,118 & 2,83 \\
\hline - Aktif & $60(60)$ & $40(40)$ & & \\
\hline
\end{tabular}




\begin{tabular}{|c|c|c|c|c|}
\hline \multicolumn{5}{|c|}{ Asupan Energi } \\
\hline - Tidak & $42(61,8)$ & $26(38,2)$ & 0,769 & 0,83 \\
\hline - Cukup & $35(66)$ & $18(34)$ & & \\
\hline \multicolumn{5}{|c|}{ Asupan Protein } \\
\hline - Tidak & $50(59,5)$ & $34(40,5)$ & 0,226 & 0,55 \\
\hline - Cukup & $27(73)$ & $10(27)$ & & \\
\hline \multicolumn{5}{|c|}{ Asupan Lemak } \\
\hline - Tidak & $50(64,9)$ & $27(35,1)$ & 0,844 & 1,17 \\
\hline - Cukup & $27(61,4)$ & $17(38,6)$ & & \\
\hline \multicolumn{5}{|c|}{ Asupan Karbohidrat } \\
\hline - Tidak & $49(62)$ & $30(38)$ & 0,759 & 0,82 \\
\hline - Cukup & $28(66,7)$ & $14(33,3)$ & & \\
\hline
\end{tabular}

*Uji Chi-square.

lansia dengan RO 5,5 kali. Tingkat pendidikan memiliki hubungan yang bermakna baik pada single exposure maupun multivariable exposure. Tingkat pendidikan $<6$ tahun menjadi faktor risiko bagi gangguan VF. Hasil penelitian ini sejalan dengan Chavez-Oliveros dan Farghal yang menyatakan bahwa hasil analisis regresi dari VF memiliki hubungan yang signifikan dengan tingkat pendidikan.,16 Hal ini juga sesuai dengan penelitian Beeri ${ }^{17}$ yang menyebutkan bahwa kemampuan bahasa umumnya terdapat pada pusat bahasa di area Wernicke dan Broca pada lobus frontal dan temporal hemisfer kiri dan bagian otak ini akan berkembang seiring dengan tingginya tingkat pendidikan.

Penelitian ini menunjukkan bahwa pada analisis bivariat dan multivariat, pendidikan secara konsisten berhubungan dengan terjadinya gangguan VF, namun tidak demikian halnya pada usia dan jenis kelamin. Hal ini sesuai dengan penelitian Farghaly dan Shao. ${ }^{5,18}$ Berlawanan dengan hasil penelitian ini, penelitian Chavez-Oliveros dengan pembagian subjek menjadi 4 kelompok usia yaitu 65-69 tahun, 70-74 tahun, 75-79 tahun dan diatas 80 tahun menunjukan bahwa proses penuaan terutama disebabkan oleh estrogen akan menyebabkan deteriorasi dari sistem memori semantik pada lansia wanita sehingga didapatkan hasil yang bermakna antara usia dengan VF. ${ }^{16,19}$

Penelitian ini menunjukkan bahwa pada analisis multivariat tidak adanya riwayat penyakit jantung merupakan faktor protektif bagi VF dengan RO 0,11 sehingga dapat didefinisikan sebagai seseorang dengan penyakit jantung akan memiliki risiko 9 kali mengalami gangguan VF. Sesuai dengan hasil penelitian ini, penelitian Lourenco dkk, yang menyatakan bahwa adanya asosiasi antara penyakit jantung dan arterosklerosis aorta terutama pada pasien lansia dengan angina pektoris, penyakit vaskular periferal dan operasi bypass arteri koroner. Dasar hubungan antara penyakit jantung dengan gangguan VF masih belum diketahui. ${ }^{20}$

Penelitian ini menunjukkan bahwa dengan single exposure dan multivariable exposure, obesitas, hipertensi dan diabetes melitus tidak memiliki hubungan yang bermakna dengan VF. Hubungan obesitas, hipertensi, dan diabetes melitus dengan fungsi kognitif, khususnya kemampuan verbal masih kontroversial. Hasil ini sesuai dengan penelitian Regina dkk yang menyatakan bahwa peningkatan IMT pada akan memengaruhi pada kemampuan memori non-verbal sedangkan pada perempuan akan memengaruhi kemampuan memori verbal. ${ }^{21}$ Berlawanan dengan penelitian ini, hasil penelitian di Sao Paulo mendapatkan adanya hubungan yang bermakna IMT dengan VF dan delayed recall memory, tetapi perbedaan pada penelitian ini adalah adanya kontrol terhadap tingkat pendidikan responden. Dari beberapa penelitian lain juga menyebutkan bahwa hipertensi dan kadar gula darah yang meningkat berkaitan dengan hasil fungsi kognitif yang lebih buruk. Tetapi pada penelitian cross-sectional yang dilakukan pada 384 responden di Brazil oleh Nathalia dkk menyatakan bahwa hasil VF kategori tidak 
Tabel 3. Analisis Multivariat

\begin{tabular}{lcccc}
\hline \multicolumn{1}{c}{ Faktor-faktor } & \multirow{2}{*}{$\mathbf{p}^{*}$} & RO & \multicolumn{2}{c}{ IK 95\% } \\
\cline { 4 - 5 } & & & Lower & Upper \\
\hline Penyakit Jantung & 0,023 & 0,111 & 0,02 & 0,74 \\
Aktivitas Fisik & 0,084 & 3,401 & 0,85 & 13,66 \\
Tingkat Pendidikan & 0,020 & 3,792 & 1,24 & 11,63 \\
Stroke & 0,999 & 0,000 & 0,000 & - \\
\hline
\end{tabular}

*Regresi logistik berganda; RO: rasio Odds; IK: interval kepercayaan.

memiliki asosiasi dengan hipertensi dan diabetes melitus. Penyebab hipertensi dan dibetes melitus tidak memiliki asosiasi dengan VF pada penelitian ini dapat disebabkan karena tidak diketahuinya durasi penyakit dan konsumsi obat., ${ }^{4,22}$

Penelitian ini menunjukkan bahwa single exposure stroke memiliki hubungan bermakna dengan VF. Hasil ini sesuai dengan penelitian Bonini dkk yang menjelaskan bahwa stroke dapat menyebabkan gangguan fungsi kognitif dengan instrumen verbal fluency. Instrumen verbal fluency menguji fungsi eksekutif dan fungsi penyimpanan semantik maka jika terjadi stroke, terutama yang menyebabkan afasia dengan lesi di hemisfer kiri maupun hemisfer kanan akan menyebabkan rendahnya VF. ${ }^{23}$

Penelitian ini menunjukkan bahwa dengan single exposure dan multivariable exposure, kolesterol total, LDL, HDL, dan trigliserida tidak memiliki hubungan yang bermakna dengan VF. Berdasarkan beberapa penelitian yang telah dilakukan menunjukan adanya peningkatan LDL pada pasien dengan demensia dan atau stroke. Selain itu perubahan pada serum lipid dan lipoprotein juga memiliki asosiasi dengan risiko serebrovaskular yang dapat menyebabkan demensia vaskular. Hasil penelitian ini sesuai dengan hasil penelitian kohort yang dilakukan pada 1.147 responden oleh Reitz dkk yang menyatakan bahwa tidak ada asosiasi antara dislipidemia serta penggunaan obat penurun lipid dengan gangguan kognitif pada domain memori, visuospasial, dan verbal. ${ }^{22,24}$

Penelitian ini menunjukkan bahwa dengan single exposure dan multivariable exposure, merokok tidak memiliki hubungan yang bermakna dengan VF. Hubungan merokok dengan kemampuan verbal seseorang masih kontroversial. Hasil penelitian ini sesuai dengan penelitian cross sectional oleh
Jill bahwa merokok dalam jangka lama dapat mengakibatkan gangguan kognitif pada domain fungsi eksekutif saja, tetapi jika dilihat dari hasil skor, responden yang tidak merokok memiliki skor yang lebih tinggi dibandingkan dengan responden merokok. ${ }^{25}$

Penelitian ini menunjukkan bahwa dengan single exposure dan multivariable exposure, aktivitas fisik tidak memiliki hubungan yang bermakna dengan VF. Hasil ini sesuai dengan hasil penelitian Uffelen dkk yang menyatakan bahwa peningkatan aktivitas fisik tidak memengaruhi hasil Mini Mental States Examination (MMSE) maupun VF. Tetapi aktivitas fisik pada perempuan dapat meningkatkan fungsi atensi sedangkan pada laki-laki meningkatkan delayed recall. ${ }^{26}$

Penelitian ini menunjukan bahwa dengan single exposure dan multivariable exposure, energi total, asupan protein, lemak dan karbohidrat memiliki hubungan yang tidak bermakna dengan verbal fluency pada lansia. Hal ini sesuai dengan penelitian Erin dkk bahwa asupan nutrisi yang baik dapat memengaruhi kemampuan verbal learning dan memori tetapi tidak berhubungan dengan hasil VF kategorik. Berlawanan dengan penelitian ini, penelitian Roberts dkk menunjukan bahwa peningkatan total energi dan asupan karbohidrat dapat meningkatkan risiko gangguan kognitif tetapi asupan lemak dan protein berkaitan dengan penurunan risiko demensia. Asupan karbohidrat dan protein memengaruhi gangguan fungsi kognitif secara keseluruhan terutama fungsi memori. Asupan lemak "buruk" (saturated dan trans unsaturated) dapat meningkatkan risiko gangguan kognitif, sedangkan lemak "baik" (monounsaturated dan polyunsaturated) dapat menurunkan risiko gangguan kognitif pada lansia. ${ }^{27-29}$ 
Keterbatasan penelitian ini adalah penelitian ini dilakukan secara potong lintang sehingga mungkin tidak dapat menunjukan hubungan sebab akibat yang jelas. Selain itu penelitian kami tidak mempertimbangan riwayat penggunaan obat seperti antihipertensi, dan antidislipidemia lainnya.

\section{KESIMPULAN}

Sebagian besar lansia memiliki gangguan fungsi bahasa. Tingkat pendidikan rendah diketahui secara konsisten sebagai faktor risiko gangguan fungsi bahasa pada lansia. Tidak adanya riwayat penyakit jantung adalah faktor protektif terhadap gangguan fungsi bahasa pada lansia.

\section{DAFTAR PUSTAKA}

1. Kementerian Kesehatan RI. Situasi lanjut usia (lansia) di Indonesia. Jakarta: Pusat Data dan Informasi Kementrian Kesehatan RI; 2016.

2. Kementerian Kesehatan RI. 2014. Statistik penduduk lansia. Jakarta: Pusat data dan pelayanan Kementrian Kesehatan RI; 2016.

3. Murman DL. The impact of age on cognition. Semin Hear. 2015;36(3):111-21.

4. Morelli NL, Cachioni M, Lopes A, Batistoni SST, Falcao DVDS, Neri AL, dkk. Verbal Fluency in elderly with and without hypertension and diabetes from the FIBRA study in Ermelino Matarazzo. Dement Neuropsychol. 2017;11(4):413-8.

5. Farghaly M, Hussein M, Hassan A, Hegazy M, Sabbah A. Testing of verbal fluency in egyptians: cultural and educational challenges. Cogn Behav Neurol. 2018 ;31(3):133-41.

6. Esteves CS, Oliveira CR, Moret-Tatay C, NavarroPardo E, Carli GAD, Silva IG, dkk. Phonemic and semantic verbal fluency tasks: normative data for elderly Brazilians. Psicologia: Reflexao e Critica. 2015;28(2):350-5.

7. Gallucci M, Mazzuco S, Ongaro F, Di-Giorgi E, Mecocci P, Cesari M, dkk. Body mass index, lifestyles, physical performance and cognitive decline: the 'treviso longeva (trelong)'. Study J Nutr Health Aging. 2013;17(4):378-84.

8. Patel, Birju, and N. Wilson Holland. Mild cognitive impairment, an issue of clinics in geriatric medicine. Elsevier Health Sciences; 2013.

9. Indrajaya AW, Lumempouw SF, Ramli Y, Prihartono J. Nilai normal pemeriksaan neuropsikologi Cerad di Jakarta. Neurona. 2013;30(3).

10. Borden WB, Maddox TM, Tang F, Rumsfeld JS, Oetgen WJ, Mullen JB, dkk. Impact of the 2014 expert panel recommendations for management of high blood pressure on contemporary cardiovascular practice. J Am Coll Cardiol. 2014;64(21):2196-203.

11. Suemoto CK, Gilsanz P, Mayeda ER, Glymour MM. Body mass index and cognitive function: the potential for reverse causation. Int $\mathrm{J}$ Obes (Lond). 2015;39(9):1383-9

12. Nielsen TRH, Lausten-Thomsen U, Fonvig CE, Bojsoe C, Pedersen L, Bratholm PS, dkk. Dyslipidemia and reference values for fasting plasma lipid concentrations in Danish/North-European white children and adolescents. BMC Pediatr. 2017;17(1):116.

13. Chentli F, Azzoug S, Mahgoun S. Diabetes mellitus in elderly. Indian J Endocrinol Metab. 2015;19(6):744-52.

14. Waid JL, Bogard JR, Thilsted SH, Gabrysch S. Estimates of average energy requirements in Bangladesh: Adult Male Equivalent values for use in analyzing household consumption and expenditure surveys. Data Brief. 2017;14:101-6.

15. Kemenkes RI. Peraturan menteri kesehatan Republik Indonesia nomor 74 tahun 2013 tentang angka kecukupan gizi yang dianjurkan bagi Bangsa Indonesia. Kemenkes RI [serial online]. 2013 [diunduh 31 Des 2017]. Tersedia dari: Kemenkes RI.

16. Chavez-Oliveros M, Rodriguez-Agudelo Y, AcostaCastillo I, Garcia-Ramirez N, Rojas-De-La-Torre G, Sosa-Ortiz AL. Semantic verbal fluency in elderly Mexican adults: reference values. Neurologia (English Edition). 2015;30(4):189-94.

17. Beeri MS, Schmeidler J, Sano M, Wang J, Lally R, Grossman H, dkk. Age, gender, and education norms on the CERAD neuropsychological battery in the oldest old. Neurology. 2006;67(6):1006-10.

18. Shao Z, Janse E, Visser K, Meyer AS. What do Verbal Fluency tasks measure? Predictors of verbal fluency performance in older adults. Front Psychol. 2014;5:772.

19. Hara Y, Waters EM, McEwen BS, Morrison JH. Estrogen effects on cognitive and synaptic health over the lifecourse. Physiol Rev. 2015;95(3):785-807.

20. Lourenco J, Serrano A, Santos-Silva A, Gomes M, Afonso, Freitas P, dkk. Cardiovascular risk factors are correlated with low cognitive function among older adults across Europe based on The SHARE database. Aging Dis. 2018;9(1):90-101.

21. Wright RS, Cole AP, Ali MK, Skinner J, Whitfield KE, Mwendwa DT. Examining the influence of measures of adiposity on cognitive function in middle age and older African Americans. Arch Clin Neuropsychol. 2016;31(1):23-8.

22. Takeda JRT, Matos TM, De-Souza-Talarico JN. Cardiovascular risk factors and cognitive performance in aging. Dement Neuropsychol. 2017;11(4):442-8. 
23. Bonini MV, Radanovic M. Cognitive deficits in poststroke aphasia. Arq Neuropsiquiatr. 2015;73(10):840-7.

24. Reitz C, Luchsinger J, Tang MX, Mayeux R. Impact of plasma lipids and time on memory performance in healthy elderly without dementia. Neurology. 2005;64(8):1378-83.

25. Reed AC, Harris JG, Olincy A. Schizophrenia, smoking status, and performance on the matrics Cognitive Consensus Battery. Psychiatry Research. 2016;246:1-8.

26. Van-Uffelen JG, Chinapaw MJ, Van-Mechelen W, Hopman-Rock M. Walking or vitamin B for cognition in older adults with mild cognitive impairment? A randomized controlled trial. Br J Sports Med. 2008;42:344-51.
27. Richard EL, Laughlin GA, Kritz-Silverstein D, Reas ET, Barrett-Connor E, McEvoy LK. Dietary patterns and cognitive function among older communitydwelling adults. Nutrients. 2018;10(8):E1088.

28. Roberts RO, Roberts LA, Geda YE, Cha RH, Pankratz VS, O'Connor HM, dkk. Relative intake of macronutrients impacts risk of mild cognitive impairment or dementia. J Alzheimers Dis. 2012;32(2):329-39.

29. Devore EE, Stampfer MJ, Breteler MMB, Rosner B, Kang JH, Okereke O, dkk. Dietary fat intake and cognitive decline in women with type 2 diabetes. Diabetes Care. 2009;32(4):635-40. 